\title{
The Role of Global Civil Society in Global Governance
}

\section{Vivek Kumar Mishra}

School of Law Justice \& Governance, Gautam Buddha University, Greater Noida, India.

Email: mishrajnu@gmail.com,vivekm@gbu.ac.in

Received July $13^{\text {th }}$, 2012; revised August $15^{\text {th }}, 2012$; accepted September $4^{\text {th }}, 2012$

\begin{abstract}
Globalisation is the most defining feature of the twenty first century. The globalised world faces new challenges such as climate change, terrorism, poverty and economic crisis. These challenges having no borders and cannot be solved by any country alone. These can be resolved only by coordinated efforts at the global level. Therefore, the world needs more effective forms of collaboration between international organisations, governments, the private sector and global civil society. The paper is an attempt to elucidate the role of global civil society as a means of global governance for the resolution of many global issues. More particularly, the aim is to understand how global civil society organisations are shaping the processes of global governance, and what their implications might be for the quality of governance at the international level.
\end{abstract}

Keywords: Global Civil Society (GCS); Global Governance; International Non Governmental Organisations (INGO); Trans National Corporations (TNCs)

\section{Introduction}

The term "Globalisation" broadly means "the integration of economies and societies through cross country flows of information, goods, services, ideas, technologies, capital and people (Rangarajan [1])”. Roland Robertson, [2] refers it "as the compression of the world and the intensification of consciousness of the world as a whole". Wallerstein [3] has aptly remarked that "globalisation is a driving force of the capitalist world economy". Scholte [4] has stated it as "an ensemble of developments that make the world a single place, changing the meaning and importance of distance and national identity in world affairs". Globalisation is broadly viewed as a contemporary process of increasing intense interconnectedness, interdependence and integration of economies across borders and communities in different spheres of human life (Chaudhary, [5]).

In the process of globalisation, interactions take place from the local and national to the supranational level. The encompassing changes in technological, cultural, political and especially economic domains can be characterised as supranationalisation. The increasing supranational character of many issues, i.e. terrorism, political Islam, public health, the environment, trade and investment is giving the birth of new global problems (Goodhart, [6]). The supporters of globalisation especially hy-

\footnotetext{
${ }^{1}$ Market Fundamentalism is the belief, prominent during the conservative ascendancy of the Reagan and Thatcher years tat free markets are always the best way to resolve economic problems.
}

per globalist focuses on the inflow of foreign investment and higher economic growth, technological advances, shared knowledge, generation of new employment and, in turn, improving quality of life. On the contrary, the opponents strongly oppose globalisation and in particular of the "market fundamentalism." According to this view, globalisation is good for the rich, does little to help the poor and in fact is a major cause of inequality in the world.

The sovereignty of the state depended on a territoriality geography where all social, economic, political and other transactions occur at or within a fixed location. With the end of territorialism and emergence of globalism, it is said that statism has lost its foundation because state is unable to control over financial capital, drug trafficking, terrorism and other global problems. The globalisation has enforced the "retreat of the state" and brought governance into the hands of corporate powers and private markets that further their own personal interests at the expense of the poor (Yamini Aiyar, [7]). The role of global civil society has become important for analysing the asymmetric power relations and the undesirable conesquences of globalisation.

\section{Civil Society}

The idea of civil society is deeply rooted in the tradition of Western political thought. The term "civil society" can be traced through the works of Cicero and other Romans 
and Greek philosophers. In modern political philosophy it emerged along with the rise of capitalism and liberal political thought. In the eighteenth century, the notion of civil society was primarily understood as a political society by thinkers like Hobbes and Locke and used to describe it as a "sphere of social activity" and distinguished from the state (Pietrzyk [8]).

The concept of civil society has been defined by many scholars in various ways. Hobbes has defined it as "a creation and the application of force by the state to uphold the contract and so forth (Copleston, [9])”. In Locke's conception, civil society has two dimensions. On the first, it provides redress and security against anarchy and arbitrariness of the "state of nature" and on the other, through the devolution of legislative powers "in collective bodies of men, call them senate or parliament gives them security against the arbitrariness of the government (Ajit Roy, [10])”.

German philosopher Hegel embraces the civil society in the realm of economic interest, private property and in totality of the material conditions of life. While conceding the duality of political society (the state) and civil society (material conditions of life), he stressed that the concrete freedom consists in their identity (Marx, [10]). In his work Philosophy of Right Hegel equated civil society as a category clearly on a par with the family and the state (Hegel, [11]). In his organic perspective, he writes, "the state exists to protect common interests as it defines them by intervening in the activities of civil society (Hyden, [12])". Hegel's definition of civil society follows the classical economists view of the free market: "an association of members as self-subsistent individuals in a universality, which, because of their self-subsistence, is only abstract. Their association is brought about by their needs, by the legal system - the means to security of person and property - and by an external organization for attaining their particular and common interests (Hegel, [13])”.

Marx viewed, society as a whole as a bourgeois society. Contrary to Hegel, Marx' assumed that the state, which is an instrument of ruling class, will disappear with the disappearance of classes. "If for Hegel civil society should resolved into the ethical universal entity of the state, Marx resolves it into itself through the future negation of the existent distinction between civil society and the state and a future unity of human existence (Seligman, [14])".

Antonio Gramsci writings have created the new interest in civil society and its role and potentialities in contemporary socio political life. According to Gramsci, "there are two major superstructural levels: the one that can be called civil society that is the ensemble of organisms commonly called 'private' and that of political society or the state (Gramsci, [16])". These two levels correspond on the one hand to the function of "hegemony" in which the dominant group exercises throughout society and on the other hand, of the direct domination or command exercised through the state (Gramsci, [15]). He used this concept in his elaboration of politics vis-a-vis a number of distinct spheres, such as conception of hegemony, war of position and war of manoeuvres, role of intellectuals and so on.

The conceptual history of civil society provides a philosophical perspective, which is indispensable for the examination of the contemporary debate on civil society. The civil society exists "when people make combined efforts through voluntary associations to mould rules: both official, formal, legal arrangements and informal social constructs. In terms of membership, it encompasses enormous diversity. It includes academic institutions, business associations, development cooperation groups, environmental campaigns, farmer's groups, human rights advocates, relief organisations, peace activists, professional bodies, women's networks, youth campaigns and more (Scholte, [16])". In terms of organisational forms, it includes formally constituted and officially registered groups as well as informal associations (Scholte, [16]). Thus the civil society organisations are one that promotes the public good, encourages empowerment and people's participation.

\section{Global Civil Society}

Global Civil Society (GCS) has emerged as an aspect of globalisation in the globalised world. Mary Kaldor defines, "global civil society is about "civilising" or democratising globalisation, about the process through which groups, movements and individuals somewhat can demand a global rule of law, global justice and global empowerment (Kaldor, [17])”. Further, Kaldor, Anheier and Glasius, have visualised that "the GCS both feeds on and reacts to globalisation. This seems to be reflected in a strong and positive correlation between clusters of globalisation and clusters of GCS (Anheier, [18])”. They have defined GCS as "the sphere of ideas, values, networks and individuals located primarily outside the institutional complexes of family, market, and the state, and beyond the confines of national societies, polities and economies (Kaldor, [19])”. The participants of GCS and their values are "... at least in part, located in some transnational arena and not bound or limited by nation-states or local societies (Kaldor, [19])". Thus GCS can be defined as the sum of laws, policies and institutions that constitute, and mediate trans-border relations between states, cultures, citizens, intergovernmental and nongovernmental organisations and the market.

\section{Nature of Global Civil Society}

Global Civil Society has started to work to promote a truly democratic and participatory public sphere at the 
global level. In this sense, "it has becomes a global public sphere comprising active citizenship, growing selforganisation outside formal political geographies (Jenlink, [20])". GCS is also considered as a realm of socio-political activity created domestically and internationally by the expansion of capitalist social relations, where modern social movements pursue their stated goals. The main agencies associated to the rise of a GCS, are the INGOs and transnational advocacy groups etc.

The civil society reflects its global nature in a real sense when campaigns adopted by the transborder organisations especially International Non Governmental Organisations (INGOs), voluntary associations self organise with the purpose of resolving global problems and, are motivated by sentiments of transnational solidarity (Scholte, [16]). According to the Union of International Associations "there were in 1998 some 16,500 active civic bodies whose members are spread across several countries [21]". There are some global bodies which are unitary and centralised in nature, for instance, the World Economic Forum (WEF), which assembles some 900 transborder companies under the motto of "entrepreneurship in the global public interest (Scholte, [16])”. There are some global organisations, which are temporary in nature that pursues a campaign around a particular issue. For example, on various occasions civil society groups have combined forces with development and/or environmental NGOs to lobby the World Bank on one or the other of its projects which are reflecting negative consequences (Fox and Brown, [22]).

Global Civil Society is primarily concern with the issues that are transnational in nature. For example, in addressing the issue of climate change, various civic associations and INGOs have campaigned on ecological problems, like the loss of biological diversity and the depletion of ozone layer that have a supra-territorial impact (Jan Aart Scholte, [23]). GCS has played an important role in international politics. In the late 1990s, it gained public visibility primarily as a popular resistance movement challenging the institutions and policies of economic globalisation. The term GCS was printed in a major world newspaper in 1991, when Eduard Shevardnadze [24] the then Soviet Foreign Minister, saw the possibility of a new world order based on the rule of law at the global level. He wrote, "It seems to me that from an historical perspective we are moving towards the formation of a global civil society based on the precepts of law. If this is the case, then it would be worth seeing whether we couldn't approach international problems and challenges more or less in the way that democratic systems resolve domestic issues (Shevardnadze, [24])”. The statement has highlighted the importance of GCS.

There are several factors who have contributed in the emergence of the concept of GCS. The capitalism, par- ticularly through the integration of global financial markets has assumed a new global form (Coleman [25]). Wapner [26] adds, "While many regions have possessed market economies for centuries, there is now a globalised marketplace in which individuals and corporations produce, transport, and sell products the world over. The globalisation of markets circumscribes a domain across national boundaries in which people can interact free from complete governmental penetration and extends the experience of private economic activity”. O’Brien [27], in his study on Global Activism around World Economic Institutions has described that "the increasing economic interdependence amongst states is stimulating the process of GCS. In addition, the states are currently confronting many global problems such as climate change, stability of financial markets, and the protection of human rights that's why they have moved to set up more and more intergovernmental organisations, which are operating on a global scale (O’Brien, [27])”.

Finally, GCS emerged as a major social force in the late twenty century to resist an assault on public life and democracy by the institutions of economic globalisation. Initially, the resistance was centered on the Bretton Woods Institutions (Vujadinovic [28]). Subsequently, the resistance directed its attention to the global corporations and the financial markets in the developed and developing regions. Consequently the high concentration of global civil society organisations is found in the developed and developing world.

Global civil society organisations have raised many questions concerning to contemporary global economy, in relation to transborder production, trade, investment, money and finance (Vujadinovic, [28]). The activism of these organisations has been directed towards at global governance agencies like the United Nations, the Bretton Woods institutions, the Organisation for Economic Cooperation and Development (OECD), and the World Trade Organisation (WTO) (Vujadinovic, [28]. These institutions are primarily concerned with the arena of global governance.

\section{Global Civil Society and Global Governance}

It is argued by many scholars that the globalisation is altering the general position of the state. The rise of supraterritoriality has broken the state's effective monopoly on governance. As Scholte, [16] argued that "the elections centered on the state are not by themselves an adequate expression of citizenship and democracy. After all, substantial regulation now also occurs through public multilateral agencies like the IMF and the Bank for International Settlements (BIS) where the states have little direct influence (Scholte, [16])". The transnational networks of the civil society organisations, especially, the 
INGOs such as Amnesty International, Greenpeace, Oxfam International, have spread across national borders and has served and serving as a source of governance through dissemination of information, formation of open forums for dialogue and debate, and advocacy of greater democracy, transparency and accountability in governmental and multilateral institutions (Patrick Hayden, [29]). Global civil society has therefore come into central role when citizens have attempted to acquire a greater voice in post-sovereign governance.

The exponential growth of INGOs since the 1970s has been matched by their increasing influence over diverse aspects of international relations (Peter J. Spiro, [30]). According to the Yearbook of International Organizations [31], the number of international NGOs has risen from approximately 2795 in 1974, to 14,333 in 1989 to 20,851 in 2003 . The time period of 1990 s is very unique in the sense that, the greater cumulative numbers of INGOs as well as their greater willingness for direct involvement in governance institutions as indicated by the exponential growths in the number of INGOs. The rise of number's shows that globalisation has certainly produced a fresh wave of transnational activism which might reasonably be described as constituting a GCS and new frameworks of international political rule known as "global governance".

The International relations theorists, James Rosenau employed the theoretical dynamics of global governance as a way to model the international system. The theories of global governance draw attention to the increasing importance of global civil society. The global governance is "an analytic concept that builds on and expands prior neoliberal theories of international regimes or globalisation (Meyer, [32])”. Global governance is generally viewed as the management and resolution of global issues within a political space that has no single centralised authority. It is as an "efforts to bring more reliable and orderly responses to social and political issues that go beyond the capacities of states to address individually (Gordenker and Weiss, [33])". These definitions indicates that the global governance deals with the interdependent nature of decision making and the attempt by actors to manage or produce more orderly responses to common problems. Global Governance is generally refers to problem-solving arrangements at the global level.

The influence of global civil society in international relations has been increased in global governance. Global governance theorists such as Leon Gordenker and Thomas Weiss have spoken of the "pluralisation" of this phenomenon through the incorporation of NGOs and other non-state actors into the governance process. The constituent NGOs working in different sectors can interact with these organisations. As a consequence, grassroots groups get a voice and attempt to influence po- licy-making (Gordenker and Weiss, [33]). Similarly, in their study, Robert O’Brien, Jan Aart Scholte and Marc Williams [34] have highlighted "the development of a "complex multilateralism", ${ }^{2}$ which, in response to GCS Organisations pressure, has incrementally pluralised the governing structures so that, multilateral economic institutions are moving beyond their inter-state mandates to actively engage civil society actors in different countries." The example is the role of International Telecommunication Union (ITU), which assists in governing, and setting standards in telecommunications issues among countries (Kontrak Belajar, [36])”. The international regimes are closely associated to the international organisations and international treaties. However, international regimes are institutions, which are non material phenomena unlike other international organisations (Ryo Oshiba, [37]).

Gordenker and Weiss have recognised the role of GCS organisations and their participation in the global governance. According to them "the NGOs participation can be stretched back to the founding of the International Labour Organisation (ILO) in 1919 and the establishment of the United Nation's Economic and Social Council (ECOSOC) in 1946 (Alejandro Colas, [35])”. It was the ECOSOC that laid down the conditions of NGO accredittation at the United Nations, which determined many of the main features of the system as it still operates today (Willetts, [38]). The UN Charter's Article 71, [39] have incorporates the provisions for the NGOs as a consultative status (Otto, [40]). It is simply to underline, how the ECOSOC framework for NGOs consultative status has been the basis of those UN world conferences on environment Rio de Janeiro,1992, Human Rights Vienna, 1993, and conference on women at Beijing, 1995, which have reflected as representatives of the global civil society. The transformative role of NGOs has becomes apparent from these conferences (Alejandro Colas, [35]).

Ronaldo Munck states, "It is very significant that the International Confederation of Free Trade Unions had demanded a place at the "top table" at Copenhagen conference in keeping with the International Labor Organization tripartism. It was only after the Copenhagen event, in which it eventually participated as part of the NGO Forum, that the International Trade Union movement began to conceive of itself as, effectively implication part

${ }^{2}$ O’Brien declares that their concept of "complex multilateralism” is shift away from the conventional understanding of multilateralism; as a basic institutional form coordinating relations amongst three or more states. It originated in a desire to explore the relationship between multilateral economic organisations and citizens. The practices of "complex multilateralism” emerge whereby governance in these areas lies in the contestation and cooperation between the WTO, member-states, other intergovernmental organizations, non-governmental organizations and civil society, and private business interests. This approach provides the tools for dealing with the full range of actors involved, especially nonstate actors. 
of the GCS (Munck, [41])”. The report of the Commission on Global Governance 1995 made a first step proposal for an annual World civil society forum linked with the regular sessions of the UN General Assembly.

The Global Governance Commission 1995, proposed that an annual forum of civil society should be held at UN headquarter, and should consist of representatives of civil society organisations accredited to the General Assembly. In the following years the proposal was included on the agenda of the General Assembly's working group on the strengthening of the United Nations system. This initiative was welcomed as "bold and imaginative" by then UN Secretary-General, Boutros Boutros-Ghali, who advocated the creation of "representing associations" of NGOs whose representatives would work with the United Nations. [42]

The influential groups especially INGOs have became an effective instrument of global governance (Munck, [41]). "The governance has been viewed primarily as intergovernmental relationships and it involves NGOs, citizen's movements, multinational corporations, and the global market. The NGOs and intergovernmental organisations grope, sometimes cooperatively, sometimes competitively, sometimes in parallel towards a modicum of global governance on its own way" (Gordenker \& Weiss, [43]). Thus global governance is an effort to bring collaboration and cooperation among governments and others who seek to encourage common practices and goals in addressing global issues (Gordenker \& Weiss, [43]).

The government is the governing body of a nation or community to rest with formal institutions and so on. James Rosenau and Ernst-Otto Czempiel's have argued that "world affairs have shifted from a system of government to governance retains the notion that to govern is to provide the institutionalised norms and frameworks for action (Langley, [44])". Global civil society is necessary to provide accountability in a system of global governance because it is seen as outside of the government and emerges as a domain that simultaneously reacts to the "internationalisation" of the state. I affirm the views of Alejandro Colas that "the agents of the GCS fulfill a functional or operational role as grassroots partners of multilateral institutions in the administration of global governance” (Alejandro Colas, [35]).

\section{Global Civil Society, Global Governance and Nation State}

There is an intense debate and divergent views on the nature and future of the nation-state in the era of globalisation. Some scholars views that there is a trend towards the end of the nation-state or erosion/weakening of the nation-state; others are held that there is a trend of forced retreat of the welfare state, adaptation of nation- state to the neoliberal globalisation, and finally some are views that neither weakening nor end of nation-state and the state is both victim and facilitator of globalisation. The global citizen is represented more clearly and directly not by governmental bodies but by a variety of organisations that are at least relatively independent of nationstates (Hardt and Negri, [45]).

The expansion of the role of global civil society and global governance should not be seen as the end of state sovereignty. The institutions of global governance-many social movements that operate within global civil society, can and do engage with the institutions of global governance, and indeed influence the operation and policies of these institutions (Alejandro Colas, [35]). It is, however, to insist that "the interaction between GCS and the institutions of global governance is still mediated through the structure of state sovereignty in ways that prevent the superficial domestic analogy between the state and civil society on the one hand, and GCS as a counterpart to international institutions of global governance on the other (Alejandro Colas, [35])".

The most influential formulation of this promise behind globalisation is the institutions of global governance and global civil society, which is found in Held's proposals for "cosmopolitan democracy". For Held, the concept of "cosmopolitan democracy" refers to "a model of political organisation in which citizens, wherever they are located in the world, have a voice, input and political representation in international affairs, in parallel with and independently of their own governments (Held, [46])”. In the debate of the decline/erosion of state sovereignty, I have the same opinion as of Fred Halliday [47]. According to him, "the erosion of the Westphalian system rests upon a contemporary optic and illusion.” The "new" nonstate actors in fact trace their heritage back to long before the nation state Westphalian system. The current interest in global civil society and global governance can be seen as simply part of a parochial shift in International relations theory from the realist or statist perspective toward a concern with non-state or civil society actors and issues (Munck, [43]).

\section{Conclusions}

Global Civil Society and global governance has become important features of contemporary international relations. Global Civil Society provides mechanism for global collaboration and coordination for resolving global problems. GCSOs organisations give voice and stimulate debates amongst citizens on the various global conflicting issues and making important contributions to the democratisation of global governance. GCSOs have been able to exert an effective influence on policy-making at the international level. These organisations are the means of global governance and transforming the norms of international politics through providing more effective solu- 
tions to local problems than national governments or even international organisations, and acting as a powerful counter-weight to traditional power politics.

Global civil society makes more aware of global issues and playing a positive and balancing role between globalisation and the nation states. It can also contribute significantly to the public education about global governance, thereby empowering citizens to involve themselves meaningfully in the regulatory processes and can stimulate public debate about current and possible future courses of global governance.

\section{REFERENCES}

[1] C. C. Rangarajan, "Responding to Globalization: India’s Answer," The 4th Ramanbhai Patel Memorial Lecture, Ahmedabad, 2006. http://eac.gov.in/aboutus/speech.htm

[2] R. Robertson, "Globalization: Social Theory and Global Culture,” Sage, London, 1992.

[3] I. Wallerstein, "The Politics of the World Economy," Cambridge University Press, Cambridge, 1984.

[4] J. A. Scholte, “Globalisation and Collective Identities,” In: J. Krause and N. Renwick, Eds., Identities in International Relations, St. Martin’s Press, New York, 1996.

[5] K. Chaudhary, "Global Civil Society, Globalization and Nation State,” Toronto, 2004.

http://www.istr.org/resource/resmgr/working_papers_toro nto/choudhary.kameshwar.pdf

[6] M. Goodhart, "Democracy, Globalisation and the Problem of the State,” Polity, Vol. 33, No. 4, 2001, pp. 527546.

[7] Y. Aiyar, "Globalisation in India: Civil Society Response," National Centre for Advocacy Studies, Pune, 2007.

[8] D. I. Pietrzyk, "Civil Society: Conceptual History from Hobbes to Marx,” Marie Curie Working Papers, University of Wales Aberystwyth, Aberystwyth, 2001. http://graduateinstitute.ch/webdav/site/political_science

[9] F. Copleston, "A History of British Philosophy: Hobbes to Hume,” Continuum Press, London, 2003.

[10] A. Roy, "Civil Society and Nation State: In the Context of Globalisation,” Economic Political Weekly, Vol. 30, No.31-32, 1995, pp. 2005-2010.

[11] Hegel, "Elements of the Philosophy of Right," Cambridge University Press, Cambridge, 1991.

[12] G. Hyden, “Julius Court and Ken Mease, Civil Society and Governance in 16 Developing Countries,” World Governance Survey Discussion Paper, London, 2003.

[13] Hegel, "Philosophy of Right," Oxford University Press, London, 1942.

[14] A. B. Seligman, “Civil Society as Idea and Ideal,” In: S. Chambers and W. Kymlicka, Eds., Alternative Conceptions of Civil Society, Princeton University Press, Princeton, 2002.

[15] A. Gramsci, “Selections from Prison Note Book,” In: Q.
Hoare and G. N. Smith, Eds., Elec Book, London, 1999.

[16] J. A. Scholte, “Global Civil Society: Changing the World," CSGR Working Paper, University of Warwick, Warwick, 1999, pp. 1-35.

[17] M. Kaldor, “The Idea of Global Civil Society,” In: G. Baker and D. Chandler, Eds., Global Civil Society: Contested Futures, Routledge, New York, 2005, pp. 103-112.

[18] H. Anheier, M. Kaldor and M. Glasius, “Global Civil Society," 2001.

http://www.lse.ac.uk/Depts/global/Yearbook

[19] H. Kaldor, Anheier, and M. Glasius, "Global Civil Society,” Sage Publications, London, 2003.

[20] P. M. Jenlink, "Globalization and the Evolution of Democratic Civil Society: Democracy as Spatial Discourse," World Futures, Vol. 63, No. 5-6, 2007, pp. 386-407.

[21] K. G. Sauer, "Union of International Associations,” Yearbook of International Organizations, Sauer, Munich, 1998.

[22] J. A. Fox and L. D. Brown, "The Struggle for Accountability: The World Bank, NGOs, and Grassroots Movements,” MIT Press, Cambridge, 1998.

[23] J. A. Scholte, “Global Civil Society,” In: L. Richard and M. Smith, Eds., Perspectives on World Politics, Routledge, New York, 2006.

[24] E. Shevardnadze, “A Democratic Way with World Affairs: New World Order? Co-operation and Not Competition in Weapons of Mass Destruction should determine the Future,” Johns Hopkins University, Baltimore, 2006.

[25] W. D. Coleman, "The Origins of Global Civil Society and Non-Territorial Governance: Some Empirical Reflections Globalization and Autonomy,” http://www.globalautonomy.ca/global1/article.jsp?index

[26] Wapner, "The Normative Promise of Non-state Actors: A Theoretical Account of Global Civil Society,” In: Wapner and L. E. J. Ruiz, Eds., Principled World Politics: The Challenges of Normative International Relations, Rowman and Littlefield, New York, 2000.

[27] R. O’Brien, A. M. Goetz, J. A. Scholte and M. Williams, "Contesting Global Governance: Multilateral Economic Institutions and Global Social Movements,” Cambridge University Press, New York, 2000.

[28] D. Vujadinovic, "Global Civil Society as Concept and Practice in the Processes of Globalization," Synthesis Philosophica, Vol. 47, 2009, pp. 79-99.

[29] P. Hayden, “Cosmopolitan Global Politics,” Ashgate Publication, Burlington, 2005.

[30] P. J. Spiro, “New Global Communities: Nongovernmental Organizations in International Decision-Making Institutions,” The Washington Quarterly, Vol. 18, No. 1, 1995, pp. 45-56. doi:10.1080/01636609509550131

[31] Yearbook of International Organizations, 2004. http://www.uia.org/statistics/pub.php.

[32] W. H. Meyer, "Indigenous Rights, Global Governance, and State Sovereignty,” Human Rights Review, Vol. 13, No. 3, 2012, pp. 327-347.

[33] L. Gordenker and T. G. Weiss, "Pluralizing Global Governance: Analytical Approaches and Dimensions,” In: T. 
G. Weiss and L. Gordenker, Eds., NGOs the UN and Global Governance, Boulder, 1996.

[34] R. O’Brien, J. A. Scholte and M. Williams, “Contesting Governance: Multilateralism and Global Social Movements,” Cambridge University Press, Cambridge, 2000. doi:10.1017/CBO9780511491603

[35] A. Colas, "The Promises of International Civil Society: Global Governance, Cosmopolitan Democracy and the End of Sovereignty,” 2001.

http://www.theglobalsite.ac.uk/press/107colas.pdf

[36] K. Belajar, "International Regimes and Global Governance,” 2008.

http://wsetiabudi.files.wordpress.com/2008/07/kuliah12.p df

[37] R. Oshiba, "International Regimes,” 2004. http://www.eolss.net/Sample-Chapters/C04/E6-32-05-04. pdf

[38] P. Willetts, “The Conscience of the World: The Influence of Non-Governmental Organisations in the UN System," Hurst \& Co., London, 1996.

[39] The Economic and Social Council may Make Suitable Arrangements for Consulting with Non-Governmental Organizations Which Are Concerned with Matters within Its Competence. Such Arrangements May Be Made with International Organizations and, Where Appropriate, with National Organisations after Consultation with the Member of the United Nations Concerned," United Nations Charter, Article 71.
[40] D. Otto, "Non-Governmental Organizations in the United Nations: The Emerging Role of International Civil Society,” The Johns Hopkins University Press, Baltimore, 1996.

[41] R. Munck, "Civil Society: Myth and Prospect,” In: R. Taylor, Ed., Creating a Better World: Interpreting Global Civil Society, Kumarian Press, Sterling, 2004.

[42] "Chronology of Calls for Non-Governmental Participation in Global Governance in the UN,” 2010. http://ungalink.org.uk/_oneclick_uploads/2010/09/un_n go_chronology.htm

[43] L. Gordenker and T. G. Weiss, "NGOs, the United Nations and Global Governance,” Lynne Rienner, Boulder, 1996.

[44] L. A. Langley, "Global Civil Society and Global Governability,” In: R. D. Germain, Ed., The Idea of Global Civil Society: Politics and Ethics in a Globalizing Era, Routledge, New York, 2005.

[45] M. Hardt and A. Negri, Empire, Harvard University Press, Cambridge, 2000.

[46] D. Held, “Introduction,” In: D. Archibugi and D. Held, Eds., Cosmopolitan Democracy, Polity Press, Cambridge, 1995.

[47] F. Halliday, "The Romance of Non-State Actors," In: D. Josselin and Wallace, Eds., Non State Actors in World Politics, Palgrave, London, 2000. 